\title{
A survey of infections in United Kingdom laboratories, 1994-1995
}

\author{
D Walker, D Campbell
}

\begin{abstract}
Aims-To identify the number and type of infections occurring in United Kingdom clinical laboratories during 1994 and 1995, following similar surveys covering 1970 to 1989.

Methods-A retrospective questionnaire survey was undertaken of 397 responding UK clinical laboratories covering 1994 and 1995. A follow up telephone survey was undertaken with each of the laboratories from which a questionnaire had been received indicating a possible or probable laboratory acquired infection during 1994 or 1995.

Results-Questionnaires were sent to 659 laboratories or organisations which were thought to have laboratories, of which 557 responded (response rate of $84.5 \%$ ). Of these, only 397 were from organisations with laboratories. Over 55000 personyears of occupational exposure were covered, and only nine cases identified, giving an infection incidence rate overall of 16.21 100000 person-years, compared with 82.7 infections $/ 100000$ person-years found in a similar survey covering 1988 and 1989, reported previously. Infections were commonest in females, in relatively young staff, in microbiology laboratory workers, and in scientific/technical employees. Gastrointestinal infections predominated, particularly shigellosis, but few specific aetiological factors relating to working practices were identified. No hepatitis $B$ cases were reported.
\end{abstract}

Conclusions-The small number of cases identified indicates high standards of infection control, though there is still room for improvement. Periodic studies of this kind are not adequate for comprehensive monitoring of the incidence of laboratory acquired infections. That will require the introduction of a routine, active surveillance programme or prospective survey which has the support and commitment of the laboratories themselves.

(f Clin Pathol 1999;52:415-418)

Keywords: laboratory acquired infections; occupational exposure; infection control

The Health and Safety at Work Act (1974) places a duty of responsibility on employers and employees to ensure, as far as is reasonable and practicable, health and safety at work. The Reporting of Injuries, Diseases and Dangerous Occurrences regulations (1995) (RIDDOR) require certain incidents, job associated dis- eases, and accidents - whether there is injury or not - to be reported to the Health and Safety Executive. It is generally accepted that there is underreporting of such occurrences. The Management of Health and Safety at Work regulations (1992) describe the requirement to undertake risk assessments to ensure, as far as is reasonable and practicable, safety and absence of risks to health in the workplace. The Control of Substances Hazardous to Health $(\mathrm{COSHH})$ regulations (1994) and the European Community Directive on the protection of workers from exposure to biological agents at work (1990) (including genetically modified organisms, cell cultures, and human endoparasites) require assessment of risk from hazardous substances and microorganisms, whether from working practice or accidental exposure.

Grist and Emslie ${ }^{1}$ have reported on a series of surveys undertaken in United Kingdom clinical laboratories over the period 1970 to 1989 examining the rates of infection for various groups of workers in clinical laboratory and postmortem rooms. These presented trends in the incidence of laboratory acquired infections within this group of responders, and showed a decline in the rates of occupationally acquired hepatitis B infection, a continuing risk of acquiring tuberculosis in postmortem room and microbiology workers, and bowel infections occurring in association with faecal bench work rather than accidents.

Case reports of a range of laboratory acquired infections have appeared in the literature, and have included arenavirus, Brucella melitensis, Escherichia coli O157, hepatitis B, human parvovirus B19, Mycobacterium tuberculosis, salmonella, and shigella. Laboratory acquired human immunodeficiency virus (HIV) infections have been described, as have parasitic and mycotic infections.

These voluntary surveys have been useful in highlighting areas of concern, but the lack of follow up of non-responders and the concentration on NHS clinical laboratories restrict their usefulness for quantifying the risks of infection experienced by workers potentially exposed to pathogens in laboratories.

In this paper we summarise the findings of a survey commissioned by the Health and Safety Executive which included a wider range of laboratories and aimed to improve the coverage by following up non-responders.

The survey set out to ascertain the annual incidence of occupationally associated infections in laboratory workers during the years 1994 and 1995, and included an assessment of which of these infections had a definite, 
probable, or possible occupational association. The survey also aimed to identify any occupational groups at increased risk of infections and any emerging infections in laboratory workers, to allow comparison with the results of previous exercises and to determine any trends in occupationally acquired infections and their relation to occupational groups and exposures. Additionally, the survey set out to compare cases of infection identified through this voluntary survey approach with cases reported to the Health and Safety Executive under the RIDDOR regulations.

\section{Methods}

The survey adopted a retrospective cohort study design, involving the use of a postal questionnaire covering 1994 and 1995 which was sent to all known laboratories and to all NHS and academic organisations which were thought to have clinical laboratories. One reminder was sent to all non-responders. All the data sought should normally be readily

Table 1 Number of laboratories, by type

\begin{tabular}{lll}
\hline Type of laboratory & $\begin{array}{l}\text { Number of } \\
\text { laboratories }\end{array}$ & $\%$ \\
\hline Diagnostic & 289 & 73 \\
Research & 57 & 14 \\
Teaching & 37 & 9 \\
Biological products & 5 & 1 \\
Other & 9 & 2 \\
Total & $\mathbf{3 9 7}$ & $\mathbf{1 0 0}$ \\
\hline
\end{tabular}

^Includes "Hospital," "NHS," and "Therapeutic IVF."

Table 2 Number of laboratories, by clinical discipline

\begin{tabular}{lll}
\hline Laboratory discipline & $\begin{array}{l}\text { Number of } \\
\text { laboratories }\end{array}$ & $\%$ \\
\hline Microbiology & 177 & 24 \\
Biochemistry & 173 & 23 \\
Haematology & 168 & 23 \\
Morbid anatomy & 142 & 19 \\
Genetics & 15 & 2 \\
Other & 66 & 9 \\
Total & $\mathbf{7 4 1}$ & $\mathbf{1 0 0}$
\end{tabular}

* These include: blood transfusion; cell biology; cellular pathology; cytogenetics; cytology; cytopathology; embryology/seminology; gastrointestinal; histology and immunology; histopathology; immunology; paediatric pathology; pathology; pharmacology; and virology.

Table 3 Person years for 1994 and 1995, by grade of staff

\begin{tabular}{lll}
\hline Grade of staff & $\begin{array}{l}\text { Person-years } \\
(1994 \text { and 1995) }\end{array}$ & $\%$ \\
\hline Technical & 30638 & 55 \\
Scientific & 9308 & 17 \\
Administrative & 6884 & 12 \\
Medical & 4682 & 8 \\
Ancillary & 2478 & 4 \\
Veterinary & 64 & 0.1 \\
Other (unspecified) & 1644 & 3 \\
Total & $\mathbf{5 5 6 9 8}$ & $\mathbf{1 0 0}$ \\
\hline
\end{tabular}

Table 4 Number of staff affected, by grade of staff

\begin{tabular}{ll}
\hline Grade of staff affected & Number of staff affected \\
\hline MLSO 1 & 3 \\
MLSO 3 & 1 \\
Trainee MLSO & 1 \\
Student & 1 \\
Technical & 1 \\
Ancillary & 1 \\
Medical & 1 \\
Total & 9 \\
\hline
\end{tabular}

MLSO, medical laboratory scientific officer. accessible within most laboratories. Potential participants included NHS laboratories, Public Health Laboratory Service (PHLS) laboratories, private clinical laboratories, Medical Research Council (MRC) laboratories, Ministry of Agriculture, Fisheries and Food (MAFF) laboratories, and appropriate university facilities. The mailing list was determined in consultation with representatives of these organisations, the Association of Clinical Pathologists, and appropriate directories.

Study items included staff numbers in each laboratory and, in each case of infection, the type of infection, year of infection, outcome, putative aetiology, and demographic details of the case. Responses relating to all grades of employee, including administrative staff, were sought for completeness, although the work associated infection risk to some grades should be extremely small. A follow up interview was undertaken by telephone with the heads of each of the laboratories from whom a questionnaire had been received, indicating a possible or probable laboratory acquired infection during 1994 or 1995.

Each possible or probable case was then compared with those held on the Health and Safety Executive database of cases notified under RIDDOR for both years.

\section{Results}

Questionnaires were sent to 659 laboratories, or organisations which were thought to have laboratories, of which 557 responded. While this gives a response rate for those sent questionnaires of $84.5 \%$, it is not possible to give a definitive response rate for the survey, as there is no complete list available of all the clinical laboratories in the United Kingdom. Of these 557 responses, only 397 were from organisations with laboratories.

Table 1 shows the type of work reported as being undertaken in responding laboratories. Seventy three per cent of laboratories covered in the survey were diagnostic, while $14 \%$ of those who responded were research laboratories, and 9\% were teaching laboratories.

Table 2 shows the laboratory disciplines covered by the responses. Most respondents reported on behalf of more than one discipline in their laboratory. A large number of clinical disciplines were covered by the survey, although $89 \%$ related to four clinical disciplines only-microbiology, biochemistry, haematology, and morbid anatomy.

Table 3 shows the whole time equivalent staffing indicating the number of person years over the two year period 1994 and 1995 in these laboratories, by grade of staff. Technical and scientific staff, which many respondents dealt with as synonymous, constituted $72 \%$ of personnel covered in the survey.

Nine infections were reported, affecting six female and three male laboratory staff, with a mean (SD) age of 34 (9.9) years (range 21 to 49 years). Grades of staff affected are shown in table 4. Medical laboratory scientific officers 
Table 5 Type of infection, by year reported

\begin{tabular}{lll}
\hline Case & Type of infection & Year reported \\
\hline A & Hepatitis C & 1994 \\
B & Cellulitis/septicaemia & 1994 \\
C & Shigella sonnei & 1995 \\
D & Shigella sonnei & 1995 \\
E & Shigella sonnei & 1995 \\
F & Shigella flexneri & 1995 \\
G & E coli O157 & 1995 \\
H & Non-specific gastroenteritis & 1995 \\
I & Mycobacterium tuberculosis & 1995 \\
\hline
\end{tabular}

(MLSOs) and trainee MLSOs accounted for more than half of the staff affected.

Table 5 summarises the types of infection reported and the year in which they were reported. The number and pattern of infections were strikingly different in the two years covered. However, the significance of the much larger number and preponderance of shigellosis and other gastrointestinal infections in 1995 compared with 1994 is not clear. None of the infections was life threatening, and with one exception (see below) all made a full recovery following mostly short periods of illness.
In the brief synopsis on each of the affected staff, shown in table 6 , some detail has had to be excluded to protect confidentiality.

Table 7 presents the infection incidence rate for each of the grades of staff covered in the survey. As in previous surveys, infections (particularly shigellosis and other gastrointestinal illness) are commonest in scientific/ technical grades of staff. This is as expected as these employees have the greatest exposure to potentially infectious material. The overall rate of 16.2 infections per 100000 WTE person-years compares very favourably with the most recent Grist and Emslie survey covering 1988 and $1989,{ }^{2}$ where the overall rate was $82.7 / 100000$ person-years. This decline in incidence continues the trend previously reported for the period 1970-1989. Even if administrative staff, who have an extremely low work related infection risk, are removed from these calculations, the resultant overall rate only rises to $18 / 100000$ WTE person-years.

Of the nine cases reported in the survey, only one (case E) could be matched with the cases held on the RIDDOR database.

Table 6 Synoptic details on each of the affected members of staff

\begin{tabular}{|c|c|c|c|c|c|c|c|}
\hline Case & Age & $\operatorname{Sex}$ & Occupation & Diagnosis & Possible cause & $\begin{array}{l}\text { Degree of certainty of } \\
\text { cause }\end{array}$ & Extent of recovery \\
\hline A & 46 & $\mathrm{~F}$ & $\begin{array}{l}\text { Ancillary staff working in } \\
\text { wash-up area for diagnostic } \\
\text { biochemistry, haematology, } \\
\text { and cellular pathology } \\
\text { laboratories }\end{array}$ & $\begin{array}{l}\text { Jaundice from hepatitis } \\
\mathrm{C} \text { infection }\end{array}$ & $\begin{array}{l}\text { May have cut her hand on broken } \\
\text { glass in the wash-up area }\end{array}$ & $\begin{array}{l}\text { Aetiology } \\
\text { considered to be } \\
\text { uncertain }\end{array}$ & $\begin{array}{l}\text { No information } \\
\text { available on recovery } \\
\text { (worker has since left } \\
\text { employment) }\end{array}$ \\
\hline B & 25 & M & $\begin{array}{l}\text { PhD student in experimental } \\
\text { animal anatomy laboratory }\end{array}$ & $\begin{array}{l}\text { Cellulitis and possible } \\
\text { septicaemia }\end{array}$ & Laboratory rat bite & $\begin{array}{l}\text { Definite laboratory } \\
\text { acquired infection }\end{array}$ & $\begin{array}{l}\text { Full recovery } \\
\text { following short illness }\end{array}$ \\
\hline C & 36 & $\mathrm{~F}$ & Microbiology MLSO 1 & Shigella sonnei infection & $\begin{array}{l}\text { Recently dealing with infected } \\
\text { specimens, but no particular } \\
\text { incident implicated }\end{array}$ & $\begin{array}{l}\text { No other obvious } \\
\text { cause so probably } \\
\text { bench acquired }\end{array}$ & $\begin{array}{l}\text { Full recovery } \\
\text { following short illness }\end{array}$ \\
\hline $\mathrm{D}$ & 30 & $\mathrm{~F}$ & Microbiology MLSO 1 & Shigella sonnei infection & $\begin{array}{l}\text { Recently dealing with specimens } \\
\text { infected with an identical } \\
\text { organism. Incident implicated } \\
\text { involved use of vessel containing } \\
\text { freeze dried reagents and } \\
\text { organisms sealed with a plastic } \\
\text { strip, which on removal is thought } \\
\text { may have produced an aerosol } \\
\text { which contaminated her }\end{array}$ & $\begin{array}{l}\text { Definite laboratory } \\
\text { acquired infection }\end{array}$ & $\begin{array}{l}\text { Full recovery } \\
\text { following short illness }\end{array}$ \\
\hline $\mathrm{E}$ & 21 & M & Microbiology trainee MLSO & Shigella sonnei infection & $\begin{array}{l}\text { Recently dealing with specimens } \\
\text { infected with identical organism } \\
\text { related to a local community } \\
\text { outbreak, although no particular } \\
\text { incident implicated, but trainee } \\
\text { only had two weeks experience of } \\
\text { bench work }\end{array}$ & $\begin{array}{l}\text { Probable laboratory } \\
\text { acquired infection }\end{array}$ & $\begin{array}{l}\text { Full recovery } \\
\text { following short illness }\end{array}$ \\
\hline $\mathrm{F}$ & 22 & $\mathrm{~F}$ & Microbiology technical worker & $\begin{array}{l}\text { Shigella flexneri } \\
\text { infection }\end{array}$ & $\begin{array}{l}\text { Recently dealing with infected } \\
\text { specimen, but no particular } \\
\text { incident implicated }\end{array}$ & $\begin{array}{l}\text { Probable laboratory } \\
\text { acquired infection } \\
\text { related to } \\
\text { manipulation of } \\
\text { cultures in enteric } \\
\text { room }\end{array}$ & $\begin{array}{l}\text { Full recovery } \\
\text { following short illness }\end{array}$ \\
\hline G & 40 & M & Microbiology MLSO 3 & E coli $\mathrm{O} 157$ & $\begin{array}{l}\text { Haemorrhagic enteritis. Recently } \\
\text { dealing with specimens infected } \\
\text { with an identical organism related } \\
\text { to a community outbreak, } \\
\text { although no particular incident } \\
\text { implicated }\end{array}$ & $\begin{array}{l}\text { Probable laboratory } \\
\text { acquired infection }\end{array}$ & $\begin{array}{l}\text { Full recovery } \\
\text { following short illness }\end{array}$ \\
\hline $\mathrm{H}$ & 27 & $\mathrm{~F}$ & Microbiology MLSO 1 & $\begin{array}{l}\text { Non-specific } \\
\text { gastrointestinal } \\
\text { infection }\end{array}$ & $\begin{array}{l}\text { Recently handling specimens } \\
\text { infected with Norwalk virus } \\
\text { related to a local community } \\
\text { outbreak, although no particular } \\
\text { incident implicated }\end{array}$ & $\begin{array}{l}\text { Possibly bench } \\
\text { acquired, possibly } \\
\text { community } \\
\text { acquired }\end{array}$ & $\begin{array}{l}\text { Full recovery } \\
\text { following short illness }\end{array}$ \\
\hline I & 49 & M & $\begin{array}{l}\text { Histopathology medical } \\
\text { worker }\end{array}$ & Clinical tuberculosis & No particular incident implicated & $\begin{array}{l}\text { Probable laboratory } \\
\text { acquired infection } \\
\text { as there was no } \\
\text { other likely source } \\
\text { of infection }\end{array}$ & Full recovery \\
\hline
\end{tabular}


Table 7 Rate of infection, by grade of staff

\begin{tabular}{lllll}
\hline Grade of staff & $\begin{array}{l}\text { Number of } \\
\text { infections }\end{array}$ & $\begin{array}{l}\text { Number of } \\
\text { person-years }\end{array}$ & $\begin{array}{l}\text { Rate of reported } \\
\text { infections (per } \\
\text { 100 O00 WTE } \\
\text { person-years) }\end{array}$ & $\begin{array}{l}\text { 95\% Confidence } \\
\text { interval }\end{array}$ \\
\hline Medical & 1 & 4682 & 21.4 & 1 to 139 \\
Veterinary & 0 & 64 & 0 & 142 to 7055 \\
Scientific & 5 & 9308 & 53.7 & 20 to 133 \\
Technical & 1 & 30638 & 3.3 & 0 to 21 \\
Administrative & 0 & 6884 & 0 & 1 to 70 \\
Ancillary & 1 & 2478 & 40.4 & 2 to 262 \\
Other & $1^{\star}$ & $\mathbf{1 6 4 4}$ & 60.8 & 3 to 394 \\
Total & $\mathbf{9}$ & $\mathbf{5 5 6 9 8}$ & $\mathbf{1 6 . 2}$ & $\mathbf{8}$ to $\mathbf{3 2}$ \\
\hline
\end{tabular}

*PhD student.

WTE, whole time equivalent. technique and use of protective equipment. Conversely, it may of course be a reflection of under-reporting or under-recording of what may be considered by staff or management as minor events.

As in any other occupational setting, there is a background level of infection which is unrelated to work activity or exposure. Consequently, the nine cases reported are unlikely all to have been occupationally acquired. Nevertheless, however effective mechanisms are for detecting and recording instances of infection among staff in individual laboratories, there will inevitably be occasions when symptomatic infections are not reported or recorded, while some other asymptomatic infections remain undetected. For example, it may well be that members of staff will have been infected with hepatitis $C$ virus, but in the absence of systematic serological surveillance they may remain undetected for a number of years. As a result, the incidence of infection found in this study is likely, if anything, to represent an underestimate of the true incidence of laboratory acquired infection in the responding establishments. Despite this, only nine cases of recorded infection in over 55000 person years of laboratory activity indicate high standards of infection control and a situation which, although there is still room for improvement, reflects well on the laboratories and those who work in them.

Finally, regardless of the success of this survey in achieving a wide coverage of United Kingdom laboratories, it is clear that neither these periodic studies nor the RIDDOR notification system is adequate to the task of monitoring the incidence of laboratory acquired infections in a comprehensive way. To achieve that will require the introduction of a routine, active surveillance programme or prospective survey which has the support and commitment of the laboratories themselves. In considering this, one further issue which needs to be addressed is who should be responsible for recording these infections: should it be the Health and Safety Officer or the Laboratory Manager? These are important issues which the Health and Safety Executive itself may wish to discuss with the various stakeholders. specific nature of the risk emphasises the importance of constant vigilance and strict adherence at all times to the appropriate level of infection control procedures.

The absence of any cases of hepatitis B infection, as in 1988-1989, was again encouraging, and reflects the sharp decline in incidence seen since 1970, a finding probably related to increased awareness, better technique, and the availability of immunisation. Furthermore, the absence of eye infections and the paucity of skin infections may indicate good
The survey was undertaken on behalf of the Health and Safety Executive with the help and support of the Association of Clinical Pathologists and of the laboratories themselves, who cooperated willingly and ably. In addition we are grateful to John Tolland for undertaking data preparation and entry, and to Amanda Burridge and Fiona Johnston for typing the paper.

1 Grist NR, Emslie JAN. Association of Clinical Pathologists' surveys of infection in British clinical laboratories, 1970-1989. F Clin Pathol 1994;47:391-4.

2 Grist NR, Emslie JAN. Infections in British Clinical Laboratories, 1988-1989. F Clin Pathol 1991;44:667-9. 